\title{
An Extra-Limital Population of Black-tailed Prairie Dogs, Cynomys ludovicianus, in Central Alberta
}

\author{
Helen E. Trefry ${ }^{1}$ and GeOfFrey L. Holroyd ${ }^{2}$ \\ ${ }^{1}$ Environment Canada, 4999-98 Avenue, Edmonton, Alberta T6B 2X3 Canada; email: helen.trefry@ec.gc.ca \\ ${ }^{2}$ Environment Canada, 4999-98 Avenue, Edmonton, Alberta T6B 2X3 Canada
}

Trefry, Helen E., and Geoffrey L. Holroyd. 2012. An extra-limital population of Black-tailed Prairie Dogs, Cynomys ludovicianus, in central Alberta. Canadian Field-Naturalist 126(1): 46-49.

An introduced population of Black-tailed Prairie Dogs, Cynomys ludovicianus, has persisted for the past 50 years east of Edmonton, Alberta, over $600 \mathrm{~km}$ northwest of the natural prairie range of the species. This colony has slowly expanded at this northern latitude within a transition ecotone between the Boreal Plains ecozone and the Prairies ecozone. Although this colony is derived from escaped animals, it is worth documenting, as it represents a significant disjunct range extension for the species and it is separated from the sylvatic plague (Yersina pestis) that threatens southern populations. The unique northern location of these Black-tailed Prairie Dogs makes them valuable for the study of adaptability and geographic variation, with implications for climate change impacts on the species, which is threatened in Canada.

Key Words: Black-tailed Prairie Dog, Cynomys ludovicianus, extra-limital occurrence, Alberta.

Black-tailed Prairie Dogs (Cynomys ludovicianus) occur from northern Mexico through the Great Plains of the United States to southern Canada, where they are found only in Saskatchewan (Banfield 1974). The current northern limit of natural occurrences for the species is at $49.20^{\circ} \mathrm{N}, 107.56^{\circ} \mathrm{W}$, in and around Grasslands National Park of Canada (GNP), near Val Marie in southwestern Saskatchewan. We found no historical reference to the species occurring further north than the general area of Cadillac, Saskatchewan $(60 \mathrm{~km}$ due north of Val Marie at $49.73^{\circ} \mathrm{N}$ ), before cultivation by European settlers (Soper 1938). Prairie dogs (Cynomys spp.) have been subject to poisoning, shooting, plague epizootics, flooding, and overall widespread harassment, such that they currently occupy less than $2 \%$ of their previously extensive historical range across the Great Plains of North America (Knowles et al. 2002). Black-tailed Prairie Dog colonies in Saskatchewan covered an area of approximately 500 ha when they were surveyed in 1970 (Kerwin and Scheelhaase 1971), a time when Black-tailed Prairie Dogs were still being killed by local ranchers. By 2009, the colonies $(N=18)$ had expanded to an area of approximately 1230 ha (Pearce and Kirk 2011).

This article documents the history and existence of a colony of free-living Black-tailed Prairie Dogs that escaped from captivity at the former Polar Park, which was owned and operated by Al Oeming near Edmonton, Alberta. This small colony is located over $600 \mathrm{~km}$ north of the species' natural range and is the only wild colony in Canada outside of Saskatchewan. Due to its isolated northern location and self-sustaining nature, we believe it is worthwhile to document its circumstances.

\section{History of the Black-tailed Prairie Dog Colony}

Al Oeming opened the 567 ha (1400 acre) Alberta Game Farm, later known as the Polar Park, in 1959.
Among the animals he displayed were three Blacktailed Prairie Dogs, a male and two females, originating from the Dixon ranch colony southeast of Val Marie near Grasslands National Park in 1956. In 1963, he introduced two additional males and three females, taken from near Sioux Falls, South Dakota ( $\mathrm{Al}$ and Todd Oeming, personal communication). Since the closure of the Polar Park in the late 1990s, the Black-tailed Prairie Dog colony has slowly expanded. The colony is located $12 \mathrm{~km}$ from the southeast corner of Edmonton and $300 \mathrm{~m}$ north of Highway $14\left(53.4284^{\circ} \mathrm{N}\right.$, $\left.113.1669^{\circ} \mathrm{W}\right)$. The entrance to the old Polar Park is still fenced, making the 567 ha inaccessible to the public without permission from the private landowner. The fence does not impede the movement of ungulates and is not near the colony. The current colony is $120 \mathrm{~m}$ east of the enclosure where Black-tailed Prairie Dogs were briefly displayed in 1959 before they escaped by digging under the cement wall and apron. The intervening unoccupied land contains a depression (flooded in April 2011) and a steep 30 degree slope that are not suitable habitat for Black-tailed Prairie Dogs (Knowles 1982). They moved into a pasture clearing in the forest, used to house camels and North American Elk (Cervus elaphus) at the time. When the grazers and fencing were removed, the Black-tailed Prairie Dogs took advantage of the post holes to initiate additional new burrows (Todd Oeming, personal communication). The animals were never controlled by poisoning or shooting and were never supplemented with food.

\section{Current Status of the Black-tailed Prairie Dog Colony}

On 23 April 2011, we used a Garmin 76 GPS to measure the colony area by walking the outer perimeter from active burrow to active burrow. The colony covered 1.96 ha and had a perimeter of $819 \mathrm{~m}$. Its shape was irregular, with a maximum north-south extent of 
$244 \mathrm{~m}$ and east-west width of $188 \mathrm{~m}$. We counted 424 active burrows in the colony, including all burrows with sign of digging, recent droppings, or clipped vegetation. Due to the rolling terrain and lack of a high vantage point, we were unable to get a good count of the number of animals. However, we counted 51 animals and estimate there are fewer than 100 animals.

The colony is on a rolling glacial landscape typical of the Cooking Lake Moraine and at $750 \mathrm{~m}$ ASL (above sea level) it is about $100 \mathrm{~m}$ higher than the surrounding plain. The area is a unique transition zone in the area between the Aspen Parkland ecoregion in the Prairies ecozone and the forest of the Boreal Transition ecoregion in the Boreal Plains ecozone (Ecological Stratification Working Group 1996). Grey luvisols are the common soil in the wooded areas (Geowest $1997 *)$. The area receives $20 \%$ more precipitation on average than the central parkland or northern boreal forest, but temperatures are comparable. The area contains scattered mature trees, including eight elm trees (Ulmus spp.) along a dirt road that bisects the colony. Coniferous trees are interspersed, and some of the burrows are near tree trunks. The colony is bordered by a dense spruce (Picea spp.) forest (Figure 1), a lake, mixed aspen (Populus spp.) forest, and an occupied yard. However, uninhabited grassland areas still exist for expansion on two sides of the colony. The ground cover was never seeded and currently is a mix of native and introduced grasses and forbs. There are no entirely barren patches other than the burrow mounds themselves. The perimeter of the area is actively mowed by the landowner annually due to the tall vegetation. The area no longer contains large grazers other than White-tailed Deer (Odocoileus virginianus). In 2011, the Black-tailed Prairie Dogs appeared to have abandoned areas with tall vegetation growth $(>20 \mathrm{~cm})$ around the periphery of the colony, as evidenced by in-filled burrows, but the interior of the colony remained well occupied. We saw domestic cats (Felis catus) and Coyotes (Canis latrans) in the area but American Badgers (Taxidea taxus) have not been seen for many years ( $\mathrm{Al}$ and Todd Oeming, personal communication).

\section{Discussion}

The Oeming colony has been in existence for about 50 years, originating from eight animals. While the density of burrows is not a reliable indicator of the number of animals in a colony, the density of burrows in the Oeming colony (216 burrows/ha) is higher than the usual range of 30-100 burrows/ha (King 1955). Although it has expanded, the colony remains small in size ( $\sim 2$ ha), suggesting a slow growth rate. Knowles et al. (2002) reported that it is often said that Blacktailed Prairie Dogs can spread quickly. A colony can recolonize rapidly after plague, but it is a long-term process for new colonies to develop. When Stelfox $\left(1966^{*}\right)$ visited the Snake Pit colony in the Val Marie area following poisoning by local ranchers in 1963, only a few animals and burrows remained. This same colony was estimated to still be small, only 0.6 ha, when it was surveyed in 1970 (Kerwin and Scheelhaase 1971), but by the next survey, in 1975 (Millson 1976 quoted in Pearce and Kirk 2011*), it was estimated at 164 ha. While mapping colonies in North Dakota, Knowles et al. (2002) reported that a new colony that was believed to have appeared in the early 1960 s was only 23.5 ha 30 years later. Although Blacktailed Prairie Dogs can reproduce more rapidly in the case of young, expanding colonies, where resources are not limiting, they normally increase relatively slowly due to a combination of reproductive factors (Hoogland 2001).

Severe winters are considered a mild threat to the Black-tailed Prairie Dog populations of Canada, while droughts and plague are considered more severe threats (Tuckwell and Everest 2009*). Droughts have been documented to reduce populations by up to $80 \%$ by affecting body weight of the females to such an extent that they are unable to reproduce (Grasslands National Park data in Tuckwell and Everett 2009*). Food in the form of native and non-native vegetation seems abundant in the Oeming colony area, which receives almost twice as much average rainfall $(60.7 \mathrm{~cm}$ vs. $34.8 \mathrm{~cm})$ and snowfall $(121.4 \mathrm{~cm}$ vs. $86 \mathrm{~cm})$ as Grasslands National Park (Geowest 1997*; Environment Canada $2012 *)$. Gummer (2005) showed that the use of torpor by Black-tailed Prairie Dogs in Canada was related to daily air temperatures and snow depth and that they use more extensive torpor bouts than southern relatives.

Sylvatic plague is an introduced and recurring bacterial disease transmitted by fleas that decimates prairie dogs in the United States. In May 2010, we discovered a small Black-tailed Prairie Dog colony (South Gillespie) in the west block of Grasslands National Park that had recently become unoccupied. A dead Black-tailed Prairie Dog found in another colony was subsequently tested and confirmed to have died from sylvatic plague (Pat Fargey, Parks Canada, personal communication). The South Gillespie colony was found unoccupied in 1970 (Kerwin and Scheelhaase 1971) but was subsequently recolonized at an unknown date. Three other small colonies reportedly disappeared historically in the east block of Grasslands National Park, where ranchers reported they died out at the same time as ground squirrels (Spermophilus spp.) (Stelfox 1966*); these Black-tailed Prairie Dog colonies never recovered. Due in part to the recent appearance of sylvatic plague, the status of the Black-tailed Prairie Dog was recently upgraded to threatened in Canada by the Committee on the Status of Endangered Wildlife in Canada (COSEWIC) (Pearce and Kirk 2011*).

The only other free-living Canadian colony we are aware of outside the Frenchman River (Grasslands National Park) area is a small colony at Moose Jaw, Saskatchewan, about $200 \mathrm{~km}$ northeast of the closest 

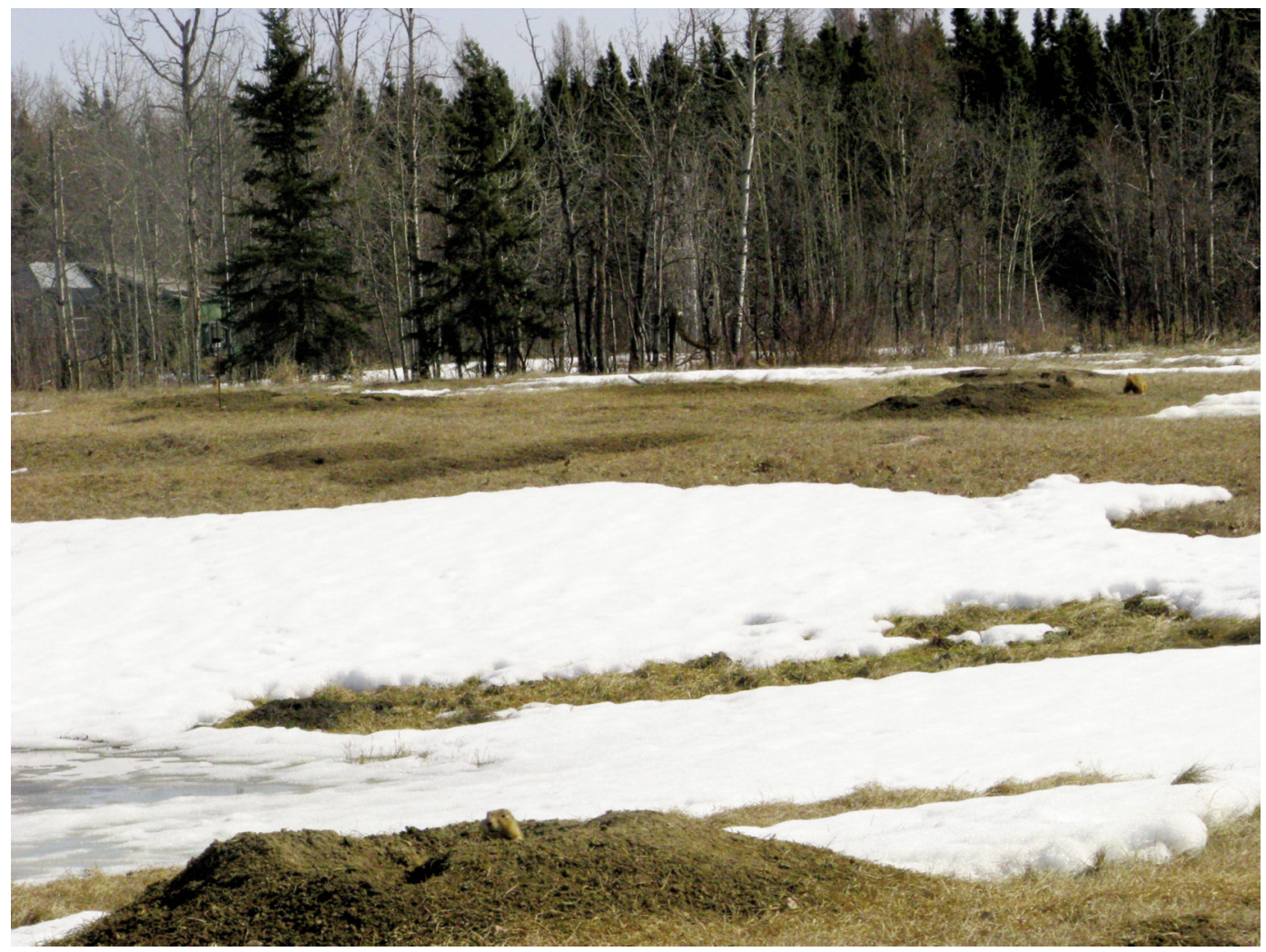

Figure 1. Dense spruce (Picea spp.) forest at the edge of the Oeming Black-tailed Prairie Dog colony, 23 April 2011. Two burrows are visible, one in the centre foreground with a Black-tailed Prairie Dog, and one in the back right near the trees, with a Black-tailed Prairie Dog near it. Photo: Helen Trefry.

wild colony. These animals are another result of escaped animals, in this case from the Moose Jaw Wild Animal Park, which opened in 1929 and closed in 1995. We were unable to find information on the origin of the animals or the status of the colony, other than that the Black-tailed Prairie Dogs still exist and the area is used as an off-leash dog area (K. Epp, personal communication). Elsewhere in the Canadian prairies, all the Black-tailed Prairie Dog colonies in zoos in Edmonton, Calgary, Saskatoon, and Winnipeg are in contained enclosures, fed, and managed, although they are outside and subject to ambient local weather.

The Oeming colony may be protected from sylvatic plague and other diseases by the large distance from the colonies to the south. The Oeming colony also appears to face less predation pressure due to the lack of American Badgers in the area. We do not know what factors may be limiting their population growth, but this extra-limital occurrence of the Black-tailed Prairie Dog demonstrates that the species can persist at more northerly latitudes and with different vegetation and soils than those that occur within the natural range of the species. The resilience to different climatic conditions in the Black-tailed Prairie Dog may also be to the species' future advantage and highlights the value of this colony in any studies of geographic variation, resilience to climate change, and adaptation.

\section{Acknowledgements}

We wish to thank $\mathrm{Al}$ and Todd Oeming for their willingness to permit access to the Black-tailed Prairie Dog colony and to share the history of Polar Park. We thank Pat Fargey and Rob Sissons, Parks Canada, for providing information on the Black-tailed Prairie Dog towns in Grasslands National Park. Finally, we thank three anonymous reviewers for providing useful comments.

\section{Documents Cited (marked * in text)}

Environment Canada. 2012. Canadian climate normals 1971-2000. National Climate Data and Information Archive. Environment Canada, Ottawa, Ontario. http://www .climate.weatheroffice.gc.ca/climate_normals/index_e.ht ml. (Accessed 16 April 2012).

Geowest. 1997. Prioritized landscape ecology assessment of Strathcona County, Alberta. Prepared for Strathcona County, Planning and Engineering Services, Sherwood Park, Alberta.

Pearce, J. L., and D. A. Kirk. 2011. In Press. COSEWIC assessment and status report on the Black-tailed Prairie Dog 
Cynomys ludovicianus in Canada. Committee on the Status of Endangered Wildlife in Canada. Ottawa. xiii +58 pages.

Stelfox, J. 1966. An investigation of the current status of prairie dogs (Cynomys ludovicianus ludovicianus (Ord). in the Val Marie, Saskatchewan area. CWSC no. 1697, CWS Progress Report 61-41-01.

Tuckwell, J., and T. Everest. 2009. Management plan for the black-tailed prairie dog (Cynomys ludovicianus) in Canada. Species at Risk Act Management Plan Series. Parks Canada Agency, Ottawa, Ontario. vi + 31 pages.

\section{Literature Cited}

Banfield, A. W. F. 1974. The mammals of Canada. Published by the University of Toronto Press, Toronto, Ontario, for the National Museum of Natural Sciences, National Museums of Canada.

Ecological Stratification Working Group. 1996. A National Ecological Framework for Canada. Agriculture and Agri-Food Canada, Research Branch, Centre for Land and Biological Resources Research, Ottawa, Ontario, and Environment Canada, State of the Environment Directorate, Ecozone Analysis Branch, Hull, Quebec. Report and national map at 1:7 500000 scale.

Gummer, D. 2005. Geographic variation in torpor patterns: the northernmost prairie dogs and kangaroo rats. Ph.D. dissertation, University of Saskatchewan, Saskatoon, Saskatchewan.
Hoogland, J. 2001. Black-tailed, Gunnison's, and Utah prairie dogs reproduce slowly. Journal of Mammalogy 82: 917 927.

Kerwin, L., and C. G. Scheelhaase. 1971. Present status of the black-tailed prairie dog in Saskatchewan. Blue Jay 29: 35-37.

King, J. A. 1955. Social behavior, social organization, and population dynamics in a black-tailed prairie dog town in the Black Hills of South Dakota. Contributions from the Laboratory of Vertebrate Biology, University of Michigan 67: 1-123.

Knowles, C. J. 1982. Habitat affinity, populations, and control of black-tailed prairie dogs on the Charles M. Russell National Wildlife Refuge. Ph.D. thesis, University of Montana, Missoula, Montana. 171 pages.

Knowles, C., J. P. Proctor, and S. Forrest. 2002. Blacktailed prairie dog abundance and distribution in the Great Plains based on historic and contemporary information. Great Plains Research 12: 219-254.

Soper, J. D. 1938. Discovery, habitat and distribution of the black-tailed prairie dog in western Canada. Journal of Mammalogy 19: 290-300.

Received 8 January 2012

Accepted 2 April 2012 